\title{
Lumen
}

Selected Proceedings from the Canadian Society for Eighteenth-Century Studies

\section{The Necessity of Amnesia: Naturalized Identities in Rousseau's La Nouvelle Héloüse}

\section{Natasha Lee}

Volume 21, 2002

URI : https://id.erudit.org/iderudit/1012273ar

DOI : https://doi.org/10.7202/1012273ar

Aller au sommaire du numéro

Éditeur(s)

Canadian Society for Eighteenth-Century Studies / Société canadienne d'étude du dix-huitième siècle

ISSN

1209-3696 (imprimé)

1927-8284 (numérique)

Découvrir la revue

Citer cet article

Lee, N. (2002). The Necessity of Amnesia: Naturalized Identities in Rousseau's La Nouvelle Héloïse. Lumen, 21, 159-177. https://doi.org/10.7202/1012273ar

Copyright (c) Canadian Society for Eighteenth-Century Studies / Sociéte canadienne d'étude du dix-huitième siècle, 2002
Ce document est protégé par la loi sur le droit d'auteur. L'utilisation des services d'Érudit (y compris la reproduction) est assujettie à sa politique d'utilisation que vous pouvez consulter en ligne.

https://apropos.erudit.org/fr/usagers/politique-dutilisation/ 


\section{The Necessity of Amnesia: Naturalized Identities in Rousseau's La Nouvelle Héloïse}

In the Discours sur l'origine et les fondements de l'inégalité, Rousseau gives us the following warning:

On commence par rechercher les règles dont, pour l'utilité commune, il serait à propos que les hommes convinssent entre eux; et puis on donne le nom de loi naturelle à la collection de ces règles, sans autre preuve que le bien qu' on y trouve qui résulterait de leur pratique universelle. Voilà assurément une manière très commode de composer des définitions, et d'expliquer la nature des choses par des convenances presque arbitraires. ${ }^{1}$

Things that seem natural, Rousseau cautions in the Discours, should not be taken at face-value. Whereas in his political theory, Rousseau tells the story of how laws or a 'collection of rules' came to be considered natural and timeless and thus historicizes the social order, his fiction tells a slightly different story, a story that recurringly calls for amnesia as a foundation of the social contract.

Indeed, a perfect couple, Rousseau suggests in Émile et Sophie, ou Les Solitaires, is one who knows how sometimes to forget. For Émile to forgive

1 Jean-Jacques Rousseau, Discours sur l'origine et les fondements de l'inégalité parmi les hommes in CEuvres complètes (Paris: Gallimard, collection de la Pléiade, 1959-1995, 5 vol.) vol. 3, 125. All translations given are my own. 'One begins by looking for the rules which, for common usefulness, it would be appropriate that men agreed upon; and then we give the name Natural Law to the collection of these rules, without any other proof than the good that we find would result from their practice. Here is, assuredly, a very convenient way of composing definitions, and of explaining the nature of things by almost arbitrary agreements.' I would like to thank the editors and anonymous readers of this volume for their careful reading and perceptive comments. 
Sophie's adulterous life he must, as he says, 'boire l'eau d'oubli'. ${ }^{2}$ Similarly, in the somewhat ideal world of Clarens in La Nouvelle Héloïse, Julie's husband advises her to forget her love for Saint-Preux in order to guarantee the success of their marriage. Saint-Preux even replies, to the news of her getting married, 'Oublions-nous, oubliez-moi du moins'. ${ }^{3}$ In these stories, starting a new life means above all founding a new social order based on identities without any past. Diverse discourses of nature are appealed to in order to design alternative contracts to the inequality in place and to legitimate differences within an order of presumed equality. ${ }^{4}$

In the following pages I will examine the two models proposed by Rousseau, analyze what they are contingent upon, and discuss the social categories and identities which are made possible by such foundations. In a first part, I consider how a rhetoric of nature is developed as the foundation of a social system, promoting the idea of a model based on universal sameness and timeless principles. I will consider how SaintPreux suggests a social model that is founded on this universal notion of nature, which is irreconcilable with the reality and rights afforded by the ancien régime. In a second section, I consider how a model of nature can become the foundation of an actual contract in the fictional universe of Clarens. When Julie and Wolmar marry and establish the social economy of their household, the latter again rests upon a concept of

2 Jean-Jacques Rousseau, Émile et Sophie, ou Les Solitaires (CEuvres complètes, Paris: Gallimard, collection de la Pléiade, 1966) vol. 4, 912.

$3 \mathrm{Ibid}$. 'Let us forget us, or at least forget $\mathrm{me}^{\prime}$. In these stories, starting a new life means above all founding a new social order based on identities without any past. In what follows I would like to suggest that Rousseau's La Nouvelle Héloïse is such a story of new social orders, a story of origins. In the novel, Rousseau stages two alternative social models which are intended to supplant the inequality instituted by the ancien régime. The novel puts forth two new social systems which require individuals to forget their past and which define social order and identities as determined by nature rather than by arbitrary rule. Despite Rousseau's own caution against justifying social positions in terms of 'naturalness', the protagonists of La Nouvelle Héloïse invoke a rhetoric of nature.

4 See Jean Ehrard's encyclopedic work on nature in the first half of the eighteenth century, where he describes how the concept of nature is initially used as a tool of criticism. This article will consider how nature is increasingly invoked as an external truth from which to explain and legitimate political and social order, following Michel Foucault and Colette Guillaumin's description of this moment as the epistemological shift in the late eighteenth century towards positivistic and scientific discourse. See Michel Foucault, Les Mots et les choses: une archéologie des sciences humaines (Paris: Gallimard, [1966] 1989) and the sociologist Colette Guillaumin, Sexe, race et pratique du pouvoir. L'idée de nature (Paris: Côté-femmes éditions, 1992). 
nature as universal principle. This time nature is redefined to legitimate a different order, one that is able to establish itself in the wake of the ancien régime system of differences. At the same time, I will show the contradictory status of such an origin or foundation: inscribed in a historical continuum, the contract nevertheless presents itself as a new beginning cut off from any past.

Consequently, this article offers a reading of Rousseau's political and literary thoughts in dialogue with each other. I explore how Rousseau's fiction itself thinks political issues and how it reconfigures social identities. My aim is not to consider the similarities or differences between Rousseau's literary works and his political philosophy but rather to show, by focusing on representations of social contracts in La Nouvelle Héloïse, how different doctrines of nature stand at odds with each other in Rousseau's fiction. Against the warning Rousseau himself issued in his political philosophy, his fiction relies in fact on a rhetoric of natural essences to establish models of social contracts and resorts to the very reversal of cause and effect he himself denounced. ${ }^{5}$

Although La Nouvelle Héloïse was a best-selling novel when it was first published, Rousseau's readers then, as critics now, stumbled over the incongruity of its two constitutive parts. From a classic tale of impossible love between a young aristocratic woman, Julie, and a commoner, her tutor Saint-Preux, the story shifts to Julie's life after she marries the man her father has chosen for her, M. de Wolmar. ${ }^{6}$ Yet, despite their apparent

5 In his Sententiousness and the Novel: Laying down the Law in Eighteenth-Century French Fiction (Cambridge: Cambridge University Press, 1985, 161), Geoffrey Bennington also points out the reversal of cause and effect implied in defining the contract as origin, a reversal that Rousseau himself problematizes in parts of his Contrat social. Bennington notes: 'In order for the contract to happen as origin, it must already have existed for the contracting parties to participate in the contract. Both of the parties would have to be before the contract, what only the contract can make them. Rousseau's contract depends on a temporal and causal reversal of which is part of a persistent logic of the après-coup. This is troubling for Rousseau's theory, as elsewhere he is concerned to establish a correct ordering of cause and effect.'

6 As Paul de Man has suggested the two sections of the novel should be read together, since 'what is involved in this division determines one's understanding of the text as a whole.' (Allegory of Reading [New Haven: Yale University Press, 1979] 18). He notes how the apparent opposition between the two sections has led to critical readings of the novel as story of polarity, between sensitivity and intellect, or as a dialectical form, as in Starobinski's interpretation of the text as oscillation of transparency and obstacle. Here, I propose to read the two parts together, as two responses to the question of political change. This brings us to consider the foundation of Clarens as the key divisional moment that opens up our reading of the text in its globality. 
dissimilarity, both sections attempt to answer the question of how a new social order begins and of what story is told to found it.

What I understand by social contract is, as Rousseau defines it, 'the maintenance of free relationships with other men'. As Carole Pateman reminds us, Rousseau's political writings present a shift away from previous contract theorists: where Locke and Pufendorf based association on each individual's ownership of oneself, an ownership that each can partially forfeit in exchange for a pact of protection, Rousseau's concept of contract rests upon each individual's right to freedom. 'For Rousseau, it therefore follows that any relationship that resembles slavery is illegitimate, and no contract that creates a relationship of subordination is valid. ${ }^{8}$ However, Pateman points out that the exception to this rule is the 'sexual contract'. In my reading I will speak of a 'social model' and a 'social contract' to distinguish between a first model that remains a proposition, a theory, and the contract of Clarens, where a marriage and a social compact are entered into.

\section{An Equality of Nature}

The first alternative social order is outlined by Saint-Preux, when he declares his love to Julie. Realizing that as a commoner he has no hope of marrying her, Saint-Preux nonetheless sees their love as possible, and encourages the reciprocal admission of their love for one another, and its consummation. Since the established order of the ancien régime only grants Saint-Preux and Julie limited rights - he being of a lesser social rank and she being a woman, thus legally a minor in the eyes of the law ${ }^{9}$ -, Saint-Preux suggests that they instead listen to the laws of nature and to their inner 'inclinations', their desire for each other. Saint-Preux is the

7 J.-J. Rousseau, Du Contrat social (Paris: Bordas, 1985) 75. See also Carole Pateman, The Sexual Contract (Stanford, Stanford University Press, 1988) 76. The well-known definition Rousseau gives in the Social Contract is: 'trouver une forme d'association qui défende et protège de toute la force commune la personne et les biens de chaque associé, et par laquelle chacun s'unissant à tous n'obéisse pourtant qu'à lui-même et reste aussi libre qu'auparavant'. For a general definition of social contract, see the entry 'social contract' in Frank Bealey, The Blackwell Dictionary of Political Science. A Users guide to its Terms (Oxford; Malden, Mass.: Blackwell Publishers, 1999).

8 Pateman, 76.

9 See Nadine Bérenguier, 'Le "dangereux dépôt": virginité et contrat dans Julie ou La Nouvelle Héloïse', Eighteenth-Century Fiction 9. 4 (1997), 447-63. 
first to admit his love to Julie, and he encourages her to do the same; he writes: 'et s'il faloit choisir entre votre cœur et votre possession même, non, charmante Julie, je ne balancerois pas un instant. Mais d'où viendroit cette amere alternative, et pourquoi rendre incompatible ce que la nature a voulu réunir?'10 The founding principle of Saint-Preux's new order is thus a notion of universal nature: the idea that all beings are equal before it and are guided by a common human nature.

Saint-Preux advocates nature as a model principle of order, as a universal power. From the very beginning of the novel, he speaks of nature as a source of truth when explaining his pedagogical theories: ' $j$ ' ai toujours cru que le bon n'étoit que le beau mis en action, que l'un tenoit intimement à l'autre, et qu'ils avoient tous deux une source commune dans la nature bien ordonné.. ${ }^{11}$ In an echo of Plato's triad of the good, the beautiful and the true, nature becomes equivalent to truth in SaintPreux's vision of a 'well-ordered' world.

In this model resounds the enduring myth of human nature, a 'family of Man' that still endures two centuries later and is subject of a critique by Roland Barthes in Mythologies:

on affirme d'abord la différence des morphologies humaines, on surenchérit sur l'exotisme, on manifeste les infinies variations de l'espèce, la diversité des peaux, des crânes et des usages ... Puis, de ce pluralisme, on tire magiquement une unité

Ce mythe de la 'condition' humaine repose sur une très vieille mystification, qui consiste toujours à placer la Nature au fond de l'Histoire ... L'humanisme progressiste, au contraire, doit toujours penser à inverser les termes de cette très vieille imposture, à décaper sans cesse la nature, ses 'lois' et ses 'limites' pour y découvrir $1^{\prime}$ Histoire et poser enfin la Nature comme elle-même historique. ${ }^{12}$

10 Jean-Jacques Rousseau, La Nouvelle Héloïse (Paris: Gallimard, collection de la Pléiade, 1966) 52, hereafter $N H$. 'If I had to choose between your heart and possessing you, no, charming Julie, I would not hesitate for a second. But where might such a bitter choice come from, and why make incompatible what nature has tried to unite?'.

$11 \mathrm{NH}, 59$; 'I have always thought that the good was only the beautiful set into action, that one was intimately dependent on the other, and that both had a common source in a well-ordered nature.'

12 Roland Barthes, Mythologies (Paris: Éditions du Seuil, 1957), 195: 'First we affirm the morphological differences among humans, and insist on exoticism, noting the infinite varieties of the species, the diversity of skins, of skulls and practices. Then, from this symbolism, we magically extract a unity. This myth of the human condition rests upon a very old mystification, to always place nature at the root of History ... On the contrary, [one] should always think of reversing the terms of this age-old imposture, 
What this vision posits is a theoretical equality among individuals, based on an abstract idea of universal human nature. Saint-Preux urges Julie to listen to 'nature' and follow her desires, to put the idea of equality into practice and follow their natural inclinations: he urges her to act as though an equality of principle were an equality of rights which does not yet exist in the ancien régime.

The breach between a timeless principle of universal equality and the reality of inequality is revealed once we look at who is speaking of nature in these terms. Although the term 'nature' appears in almost all of Saint-Preux's letters, in Julie's first hundred letters the noun appears only twice. When Julie mentions nature, it is to challenge directly the idea that they are equal before its law. She writes: 'Tout fomente l'ardeur qui me dévore; tout $m$ 'abandonne à moi-même, ou plutôt tout me livre à toi; la nature entière semble être ta complice. ${ }^{\prime 13}$ If at first, Julie considers desire as a universal and inner force, an 'ardor' that abandons her to herself, she corrects herself to describe it as an exterior force that is dangerous to her and she specifies 'ou plutôt tout me livre à toi.'

Julie notes from the start that she and Saint-Preux are not equal before Nature, and not only is her position one of inequality, but her very subjectivity is challenged. From her first mention of the term, nature is personified and becomes a person who has power over her. Julie becomes a prey, an animal rather than an individual, devoured by her desire. She becomes an object whereas Saint-Preux and nature are characters with agency, plotting together as Julie tells Saint-Preux: 'la nature entière semble être ta complice.' When Saint-Preux further attempts to convince her of nature's universality, he does so by inventing a strange new creature that endangers her identity even more. He writes: 'La sagesse a beau parler par votre bouche, la voix de la nature est la plus forte ... non sans vous la nature n'est plus rien pour moi: mais son empire est dans vos yeux, et c'est là qu'elle est invincible. ${ }^{14}$ The mirror that Saint-Preux lifts to Julie's eyes reveals to her a strange character: Julie's mouth, nature's voice, Saint-Preux fragments the bodies of Julie and of

to continuously strip nature, its "laws" and its "limits" to reveal History and establish at last the historicity of nature'.

$13 \mathrm{NH}, 39$; 'Everything feeds the ardor that devours me, everything abandons me to myself, or rather everything surrenders me to you; all of nature seems to be your accomplice; all my efforts are in vain, and I adore you in spite of myself.'

$14 \mathrm{NH}, 53$; 'Although wisdom may speak through your mouth, the voice of nature is stronger ... no, without you nature is nothing to me: but her empire is in your eyes, and it is there that she is invincible.' 
Nature, and rearticulates them both into a new identity where boundaries become unclear. In this new order of things, Julie finds her identity changed and she loses her agency: indeed, in Julie's eyes, the empire of nature reigns and there, nature is invincible. Like the automata that had fascinated the century earlier on, Julie's power is not her own and the fascination she exercises does not stem from her agency but, on the contrary, from her complete lack of agency and the illusion of her having some.

The limits and implications of reverting to nature to found a social order are reflected in the very opposition between a theory of natural equality advocated by Saint-Preux and the reality of preexisting historical inequality. Without a marriage as warrant, and having lost her virginity, Julie loses the agency she had in this society since she is neither married nor marriageable. In a system where virginity is a requirement of marriage, Saint-Preux's proposal has serious consequences for Julie since to lose her virginity is the one gesture of agency to which she has access. As Nadine Bérenguier has pointed out, in the ancien régime the status of the unmarried young woman is a socially limited one, where her virginity is her only claim to agency. Quoting Rousseau, Bérenguier speaks of virginity as a 'dangereux dépôt': 'dépôt' since Julie is the guardian of her chastity even though it is not hers to give, since she has no say in her own future marriage; 'dangereux' in the sense that without her chastity, a woman has no 'value' in the ancien régime society, has no social worth in the economy of marriage. ${ }^{15}$ The new society remains a theoretical idea of universal equality based on nature but it is still limited by the enduring ancien régime. The freedom and agency that Saint-Preux encourages her to enjoy, in a system modeled on nature, are not within her reach. Her only freedom is a passive one, the freedom not to act, not to give away what confers social value on her.

This key political scene of the novel is rarely read as such, since most readings focus on Clarens, and yet it is essential, because it introduces the notion of an order modeled on nature as ideal and egalitarian. Even though the pairing of 'nature' and 'contract' evokes, in the eighteenth century, theories of natural rights and an unmitigated notion of a sociable human nature, Rousseau did not share his contemporaries' faith

15 Bérenguier (454) also notes the contradictory agency of the woman's position, as the term 'dépôt' suggests: it is not an agency that she can profit from or act upon, but only an agency that is hers to lose, and that she must watch over. See also Carol Pateman on the notion of sexual relationships as contractual. 
or belief in such a notion. Mark Holliung points out in his study of Rousseau's critique of the Enlightenment, that

in the first version of the Social Contract Rousseau attempted to lay the "true foundations ... of natural right" and to articulate "the rules of reasoned natural right", expressions deleted from the final version, perhaps for fear that they were misleading. After all, the rights guaranteed by signing Rousseau's ideal social contract are not natural rights but the functional equivalent of the same. ${ }^{16}$

The very fact that Rousseau sometimes eschews the term 'nature' and sometimes uses it, makes his use of the notion of 'nature' in the context of social contracts all the more problematic.

\section{An Amnesic Contract}

The incommensurability of a contract of nature and a reality of social difference will be resolved, not without cost, in the second social model. When Julie marries Wolmar, a second form of social order is outlined, this time both through a marriage contract and through a larger social compact. To speak of a general social contract in reference to the household of Clarens might seem metaphorical. In fact, the moment of Clarens is a double contract - where both the civic pact and the private pact are being defined and it is the very intertwining of the civic contract and the marriage contract that I argue is being negotiated here. Although in his Social Contract Rousseau warns us against reading the family as a micromodel for the state, the link of private sphere and civil state is constantly reiterated in Rousseau's parallels between what he names domestic and civil economy in La Nouvelle Hélö̈se. Here, 'domestic' and 'civil' are used interchangeably to qualify the common project of an ideal model of social economy. ${ }^{17}$

16 Mark Hulliung, The Autocritique of Enlightenment: Rousseau and the Philosophes (Cambridge, Mass.: Harvard University Press, 1994) 68.

17 We can thus read the universe of Clarens as a form of utopia, a social model experiment, although I believe this utopia does not necessarily argue for an ideal social model but rather stages an experiment in social order, as Christie McDonald has noted in The Extravagant Shepherd (The Extravagant Shepherd: a Study of the Pastoral Vision in Rousseau's Nouvelle Héloïse, Oxfordshire: Voltaire Foundation, Thorpe Mandeville House, 1973) 172. McDonald proposes a reading of the novel as contradiction between a political ideal and a fiction of its impossibility: 'Rousseau 
The eighteenth century saw the legal and civic dimensions of the marriage contract gain importance: marriage becomes more than ever a binding contract between not only the two parties, but between the families as well, and can be understood as 'the juridical theory through which the State intended to establish its right to control marriages in order to protect the interests of the families, as well as its own'. ${ }^{18}$ Thus the microcosm of a household can be seen to model the macrocosm of a society, and even more so in the case of Clarens since the social position of each character is redefined, not only Julie's and Wolmar's position but their household's as well; the servants, Julie's closest friend Claire and her lover Saint-Preux. Though my goal is not to argue for the novel as illustration of Rousseau's political philosophy, such parallels have been made, particularly in readings of La Nouvelle Héloïse that further permit us to read these foundational moments as formulating political questions.

The contract of Clarens inaugurates a new temporality and is posited as the origin of a new social order cut off from any historical process by which it might have come into being. In fact, Julie experiences her wedding as though it were a conversion, a radical change marking a new beginning. Before her marriage to Wolmar and until her arrival at church, Julie considers this day to be the last of her life, yet on the day of the wedding Julie experiences an almost religious conversion which inaugurates a rebirth, a new life. Rather than note the spiritual dimension of this moment, she remarks that 'dans ce bouleversement général on reprend quelquefois son caractere primitif et l'on devient comme un nouvel être sorti recemment des mains de la nature. ${ }^{, 19} \mathrm{~A}$ new temporality is established, a temporality of the event that Tom Kavanagh has named 'Rousseau's moment beyond history', which could 'substract itself from the weight of time ${ }^{\prime 20}$ and opens up the story to an atemporal new order. ${ }^{21}$

seeks to express the utopian ideal of infinite happiness in an enduring present. Julie's death reveals the impossibility of this endeavor.'

18 Bérenguier, 451.

$19 \mathrm{NH}, 364$; 'In this general upheaval, we find once again our primitive character, and become like a new being that has recently come out of nature's hands.'

20 See Tom Kavanagh, Esthetics of the Moment: Literature and Art in the French Enlightenment (Philadelphia: University of Pennsylvania Press, 1996) 99.

21 Krzysztof Pomian underlines the importance of the event as rupture in L'Ordre $d u$ temps (Paris: Gallimard, 1984) 33: 'L'événement n'est pas ici un changement perçu dans le monde ambiant; c'est une discontinuité, une rupture par rapport à l'état antérieur. [...] Le problème principal que pose un événement c'est celui des rapports 
The new order emerges with its own origin and restores 'notre caractère primitif ${ }^{22}$ to ourselves, negating any historical process through which the present has been attained. As such, the origin of the new contract appears without transition and the change happens through a 'heureuse révolution', with the connotation of radical change and rejection of the past which the term would acquire a few years later with the French Revolution. The origin occurs in a present set apart from and against the historical continuum and Julie remarks: 'Je crus me sentir renaitre; je crus recommencer une autre vie. ${ }^{23}$ The event as moment beyond history defies linearity: it is both inscribed in time, as it presupposes an already constituted subject to acknowledge the originary moment, and yet at the same time it claims its status as origin, primary moment. Thus, it is possible in this time frame to restart a life, to be reborn, through a contradictory temporality that can only exist in fiction, and which establishes the foundation of the contract as always already flawed. ${ }^{24}$

For this contradiction to take place, not only must the past be forgotten but it does not even remain in a time continuum from which the present emerges. Linearity is broken and if there is mention of the past, it is as a static counter-example. Julie advises 'Hier on étoit abject et foible; aujourd'hui l'on est fort et magnanime. En se contemplant de si près dans deux états si différens, on en sent mieux le prix de celui où l'on est remonte. ${ }^{25}$ Both moments are simply juxtaposed, opposed as paradigms

entre la discontinuité qu'il est et le continu, dont la position devient centrale dans l'ensemble du champ scientifique.'

22 The term 'primitif' is particularly intriguing in this context. Signifying originally that someone or something is first, its etymology raises the very contradiction of the foundation of this new contract: indeed, how could it be possible for a character to be the 'first' once again?

$23 \mathrm{NH}, 355$; 'I felt myself being reborn, I believed I was restarting another life.'

24 Geoffrey Bennington (p. 161) comments on this contradiction, in the context of the Contrat social. He remarks that such an origin can only exist 'within what Jacques Derrida has called the "simulacre de l'instant". 'The social simulacrum of nature', Bennington writes 'can only be instituted through a simulacrum of "natural" temporality, a temporality of self-present moments. ... the statement of constitution of the people is both a description of the people constituted and the performance by which the people is/was/will be constituted.'

$25 \mathrm{NH}, 364$; 'Yesterday, we were abject and weak. Today we are strong and magnanimous. To contemplate oneself so closely in two such different states, one appreciates more the price of the state to which we have lifted ourselves.' 
of good and evil in a discourse that is now one of ahistorical values. Julie speaks of two states, and not of two stages of a social process.

The new contract is to be founded, as was the previous, upon the idea of a universal nature, an atemporal order of things that can serve as a model for an ideal society. As an alternative to the inequality of the ancien régime society, Rousseau suggests not - as Voltaire had sarcastically noted - a return to a savage or unsocialized primitive state, but a new social contract based on a human nature or essence whose timeless principles must be rediscovered. ${ }^{26}$ This shift to nature is underlined by the sudden recourse to a vocabulary of natural life: birth, rebirth, a new being. The vocabulary of Julie's conversion is physiological. Although it is enshrouded with a sense of religiousness, this conversion is not guided by religion but by nature, as Julie remarks that 'sembla corriger tout-àcoup le désordre de mes affections et les rétablir selon la loi du devoir et de la nature. ${ }^{27}$

\section{A Nature of Differences}

Whereas the first contract was founded on the idea of universal nature shared by all individuals, a nature of identical inclinations and passions, the second contract describes a world of difference, of different human

26 As I have discussed earlier in relation to Mark Hulliung's work, Rousseau's definition of human nature - contrary to that of most eighteenth-century philosophes - is never laid out once and for all in his work. For example, in the Contrat social he speaks of nature as a fiction 'which perhaps has never even existed,' leading theorists such as Asher Horowitz to write of Rousseau's vision of nature as a historical and theoretical concept - in the sense that he admits that it cannot be defined with epistemological certainty. See Asher Horowitz, Rousseau, Nature, and History (Toronto: University of Toronto Press, 1987). Similarly, Henri Vyverberg writes in Human Nature, Cultural Diversity, and the French Enlightenment (New York: Oxford University Press, 1989, 47) that this position distinguishes Rousseau from other philosophes such as d'Holbach: 'Rousseau omitted physiological analysis and, in fact, extensive theorizing of any sort on human nature as an entity.' And yet, as the work of feminist scholars such as Mary Trouille and Carol Mossman has shown, texts such as L'Émile or La Nouvelle Héloïse in this particular case, do indeed deploy an extensive vocabulary of natural sciences to speak of human nature as well as to legitimate social categories and difference in rights and duties along lines of the biological. On the idea of Nature as critical tool, see also Émile Durkheim, Montesquieu et Rousseau, précurseurs de la sociologie. Note introductive de Georges Davy. Paris, M. Rivière, 1953.

$27 \mathrm{NH}, 354$; 'An unknown power seemed to have suddenly corrected the disorder of my affections and reestablished them according to the law of duty and of nature.' 
natures. The first contract failed since it encouraged a model of theoretical equality in actions that did not correspond to an equality in rights in the existing order of the ancien régime. We will see how the second contract redefines differences in 'natural inclinations' so that they correspond to the difference in rights and duties.

The unity of nature paradoxically leads to the description of the diversity of its forms, just as Barthes had suggested in his criticism of the Family of Man exhibit: we are all equal before this law, but we are differently equal, and we are not all the same. In this sense, Rousseau's description of nature as a system of differences echoes his contemporaries' view of the world. As Robert Darnton has shown in his study of the Encyclopédie and as Michel Foucault has noted in Les Mots et les choses, among others, ${ }^{28}$ the eighteenth century inaugurated a new epistemology that makes sense of the world through its thorough description and classification. Julie herself chooses in the first instance as she details the new 'truth' that has been revealed to her after her marriage, namely, the definition of women and gender. Or rather, I should say the definition of sex, since it is not the question of femininity that is discussed or defined but precisely the question of social categories differentiated along lines of biological attributes; as Mary Trouille notes 'for Rousseau anatomy is destiny. ${ }^{2}$

However contentious the issue of women is in Rousseau's work, one idea remains in Rousseau's commentary from his era to our own: that Rousseau's portrayal of women and the definition of women he elaborates, whether for their defense or submission, is one which defines the social position of women and the category itself in terms of natural criteria and the ability to bear children. Women, in this naturalist sociology, are described among other terms, along the following lines:

28 In addition to Robert Darnton, The Great Cat Massacre and Other Episodes in French Cultural History (New York: Basic Books, 1984) and Michel Foucault, Les Mots et les choses: une archéologie des sciences humaines, many recent works in the history of ideas on the development of the social sciences, or 'sciences of man,' also describe the impulse of eighteenth-century scientific discourse to describe its world through classification. I am thinking in particular of the collection of essays edited by Christopher Fox, Roy Porter and Robert Wokler, Inventing Human Science: Eighteenth-Century Domains (Berkeley: University of California Press, 1995).

29 Mary Sedman Trouille, Sexual Politics in the Enlightenment: Women Writers Read Rousseau (Albany: State University of New York Press, 1997) 15. 
L'audace des hommes, la pudeur des femmes ne sont point des conventions, comme le pensent tes philosophes, mais des institutions naturelles dont il est facile de rendre raison, et dont se déduisent aisément toutes les autres indications morales. D'ailleurs, la destination de la nature n'était pas la même, les inclinations, les manieres de voir et de sentir doivent être dirigées de chaque côté selon ses vues, il ne faut point les mêmes goûts ni la même constitution pour labourer la terre et alaiter des enfans. ${ }^{30}$

Rousseau's account of social difference in terms of physiological criteria echoes the discourse used in other fields at the time. Indeed, in political theories found in Locke or Pufendorf, the idea of women being different is a given, a fact of nature from which culture, and more precisely political culture, can then be conceived. Defining the social position of women begins by first determining the category of women as a physiological one: women are beings who give birth, and that determines their status as a social category. The turn towards a scientific account of difference is all the more visible in medical discourse, where physicians such as de Sèze and Roussel concluded that there existed 'ineradicable physiological and psychological differences between the sexes and ascribed the intellectual inferiority of women to their "nature" rather than their education or social conditioning. ${ }^{31}$ The link between a political account and a scientific one is suddenly merged, the medical discourse delimiting social categories and rooting their very social inequality in physiological terms.

It is not only in inquiries and debates about the rights of women that a social category is biologically explained or its different status legitimated. As the work of Ludmilla Jordanova ${ }^{32}$ and Thomas Laqueur show, eighteenth-century research in 'sciences of man' increasingly sought to differentiate and classify human beings in biologically circumscribed

$30 \mathrm{NH}, 128$; 'The audacity of men and the modesty of women is not a set of conventions, as your philosophers think, but natural institutions which one can easily justify, and from which all other moral distinctions can easily be deduce. Furthermore, the goal of nature not being the same, the inclinations, ways of seeing and feeling must be directed on either side according to its views (nature's); the same tastes and the same constitution are not required to plow the land and to breastfeed.'

31 Mary Trouille mentions the works of Pierre Roussel, Système physique et moral de la femme (Paris: Vincent, 1775). Also see Paul-Victor de Sèze Recherches physiologiques et philosophiques sur la sensibilité (Paris: Prault, 1786).

32 See Ludmilla Jordanova, Images of Gender in Science and Medicine between the Eighteenth and Twentieth Centuries (Madison: University of Wisconsin Press, 1989). 
categories. Laqueur's study of the evolution of definitions of sex and of gender reveals that prior to the eighteenth century, the relevant question for social status was one of gender, whereas afterwards social identity becomes determined by the sex of an individual, rather than the social gender he or she would assume. In the case of hermaphrodites, for example, he mentions that previously their social position was determined by the exterior signs of gender roles they adopted, whereas after the eighteenth century it is the question of biological sex that is determinant - either the individual has male organs or female ones, and as such the social determination of whether one is a man or woman is from then on rooted in specific physical attributes that have suddenly been given determining meaning.

Laqueur specifies that the change in mentality was gradual, since originally, the medical consensus was rather of one sex, with two variants, female and male:

The one sex [theory] did not die. But it met a powerful alternative: a biology of incommensurability in which the relationship between men and women was not inherently one of equality or inequality but rather of difference that required interpretation. Sex, in other words, replaced what we might call gender as a primary foundational category. Indeed, the framework in which the natural and the social could be clearly distinguished came into being. ${ }^{34}$

Thus the introduction of 'naturalness' into questions of social positions and definitions that we are tracing in Rousseau's La Nouvelle Héloïse must be read in the larger context of a transformation in epistemological discourse of the time, a transformation with specific implications. ${ }^{35}$

\section{Naturalizing Social Categories}

To an even more obvious degree, these principles are put into practice in the microcosm of Clarens. Just as Rousseau had encouraged different

33 Thomas Laqueur, Making Sex: Body and Gender from the Greeks to Freud (Cambridge: Harvard University Press, 1990) 136.

34 Ibid., 154.

$35 \mathrm{M}$. Hulliung also suggests that we reread the French Enlightenment in its national context, which brings forth the importance of natural sciences such as the work and influence of Buffon. 
occupations for men and women in his Lettre à d'Alembert sur les spectacles, Julie divides the male from the female workers and it is Wolmar who explains her system's guidelines:

Selon elle la femme et le mari sont bien destinés à vivre ensemble, mais non pas de la même maniere; ils doivent agir de concert sans faire les mêmes choses. La vie qui charmeroit l'un seroit, dit-elle, insuportable à l'autre; les inclinations que leur donne la nature sont aussi diverses que les fonctions qu'elle leur impose ... chacun étant pour ainsi dire tout à son sexe. ${ }^{36}$

'Chacun étant tout à son sexe' is an awkward phrase: it is not clear in French if this means 'être à son affaire', in the sense of 'to be about one's business' where one's reproductive organs would determine one's business or work, or if it means 'être à' in the sense of 'appartenir à', where one's agency defers to his or her supposed natural category.

Differences previously existed and had mattered in the text - for example, Saint-Preux can not marry Julie because he is of a lesser rank - and these differences were until the moment of the contract presented as social inequalities. The new contract speaks of an equality that integrates natural difference. In fact, what occurs at this moment is a legitimization of one form of inequality. The philosopher Louise Marcil-Lacoste reminds us of a frequent slippage between the terms 'inequality' and 'difference' in Rousseau's texts, terms that he used throughout the two Discours to describe various social dynamics. One can think here of physical dissimilarities in the state of nature which are often by the same token inequalities of strength. We can nevertheless note two types of differences throughout his text, namely political inequalities which he condemns and natural differences which he approves. ${ }^{37}$ Thus, if we return to the issue of women's status, we find that the difference which we are here looking at is a superimposition of one

$36 \mathrm{NH}, 450$; 'According to her, husband and wife are destined to live together but not in the same manner ... The inclinations that Nature gives them are as diverse as the functions that she imposes upon them ... My own observations are rather favorable to this maxim. One does not see even savages indistinctly mixed, men and women. Such is the order whose very universality shows it to be most natural. This maxim is very well defended by her house: everyone, so to say, is entirely to their own sex.'

37 Louise Marcil-Lacoste, 'Les concurrents de Rousseau à l'Académie de Dijon', Rousseau et la critique, L. Clark and G. Lafrance ed. (Ottawa: North American Association for the Study of Jean-Jacques Rousseau, 1995) 73-81, 78. 
on the other: at the inauguration of this contract, the unequal political status of various agents is maintained, and is then justified by a natural difference.

This might appear to be a classic chicken and egg question where the question of precedence is superfluous: if a text, and even more, a fiction of a social project, stipulates natural and social inequality, what would it matter which came first? And yet, I would argue it is specifically this inversion of cause and effect - a supposedly natural difference made to explain a social inequality that already existed - that characterizes Rousseau's naturalizing conception of difference: sex in this example, or class made corporeal if we consider other excerpts. Constant natural marks are chosen to justify social categories that preexist within a dynamic of social relations. Where conventions had established inequality through a social relation, the rhetoric of nature redraws the outlines of groups according to natural marks and the mark is superimposed on a preexisting social division or relation. Foucault aptly notes this process in the case of madness in the eighteenth century: 'the gesture of alienation did not isolate misunderstood strangers, it created them.' As Foucault points out in Histoire de la Folie, and as the sociologist Guillaumin ${ }^{38}$ has described in her work on race, a group is identified at a specific historical moment and produced through a specific social relation. It is then reconstituted through eighteenth-century scientific or positivistic language as naturally different. Foucault adds:

Little by little, this first perception would become organized and perfected itself into a medical conscience, that would have formulated the illness of nature in what was until then only recognized as the ills of society. We must suppose a sort of orthogenesis going from social experience to scientific knowledge, progressing deafly from group conscience to positivistic science. ${ }^{39}$

In the case of La Nouvelle Héloïse, we find motherhood and breastfeeding to be all of a sudden natural instincts, whereas previously, both in the novel and in history, they were as Phillippe Ariès reminds us, ${ }^{40}$ a socially delimited experience and task. Motherhood was only a small part of caring for a child: the activity and the years of breastfeeding were often

Guillaumin, 171-183.

39 Foucault, [Folie et déraison] Histoire de la folie à l'âge classique (Paris: Gallimard, [1979], 1972) 94.

40 See Paul Ariès, L'Enfant et la vie familiale sous l'Ancien Régime (Paris: Seuil, 1973). 
delegated to wetnurses, motherhood differed from one class to another, and though women had more children, fewer of them actually had the experience of maternity. Motherhood per se was more 'mothershood,' and even then it shared tasks such as education with men.

\section{Literature as Critique}

The rhetoric of nature which I have attempted to outline in Rousseau's text is a trait often pointed out in his work. What I have underlined is more exactly the process by which these natural definitions are established over social relations, covering their traces. This is not simply to state that Rousseau is a philosopher of nature but that he participates in making nature. The fictional text does not simply deploy a strategy, but it also consistently problematizes it, just as the initial quotation from the Social Contract had done by revealing how first rules are established, which only later are given the name of 'Natural Laws.' Yet, alongside this main discourse, characters ceaselessly call these essences into question, challenging them with contradictory statements. According to supposedly universal laws, women are said to like mild tastes and dairy products since 'Le laitage et le sucre sont un des goûts naturels du sexe. ${ }^{\prime 1}$ However a little earlier Saint-Preux gorges himself on milky desserts, admitting 'Je fis un goûter délicieux. Est-il quelque met comparable aux laitages de ce pays? ${ }^{42}$

The key model of motherhood is the character of Claire's governess Chaillot, who has taken the place of her mother after she died and who throughout the novel underlines the social construction of the maternal role. As her name indicates - she is consistently called 'la pauvre Chaillot' - her identity is inseparable from her condition, and this makes her above all a subject/situation which insistently reminds us of its context. She is, above all, not an identity defined by essence but by her place in a system, that 'poor' woman.

With Chaillot, Rousseau creates a non-natural mother, one could even say the institution of motherhood. Defined by her role as mother, even though she is not the birth or natural mother of either girl, one could choose to read her maternal role and attitude as a sign or proof of the

$41 \mathrm{NH}, 339$; 'Dairy products and sugar are one of the natural tastes of the sex.'

$42 \mathrm{NH}, 338$; 'I had a lovely meal. Is there any dish in world comparable to the milk products of this land.' 
maternal instinct innate in all women. Yet Julie specifies that Chaillot only loved her because of Claire's own friendship for Julie. Motherhood appears thus as a responsibility reserved to women to educate, prepare and care for other human beings, the work rather than the instinct through which one becomes a woman. ${ }^{43}$

More than the idea of the work of motherhood, Chaillot raises the idea of interchangeability of the women responsible for the care of other human beings, all roles which equate to being or becoming a woman performing a 'woman's task ${ }^{\prime 44}$ : Chaillot supplements the natural mother, Claire supplements Chaillot after her death and takes care of her family, and Julie offers to help Claire. The work of caring for a household or the people of a household is the social task transferred to every woman in this novel, with varying degrees of responsibility or success. It always remains the main use of their time and the double-marker of what links women together and of their relation to other members of the social equation. If, indeed, we might have thought that Chaillot was replacing Claire's mother because of a maternal instinct, this universal essence soon falls apart when Claire, replacing Chaillot after her death to take care of her family, states that she is only doing this out of respect for 'her perfect attachment'. Respect and an accepted attribution of duty, not instinct, are what bring her to assume the responsibility of care.

As fiction both founds and undoes the rhetoric of nature inherent in eighteenth-century conceptions of social contracts, it establishes a specific role for itself in emerging discourses. Just as Saint-Preux discovers on one of his walks, nature reveals itself to be a manmade artifice:

Quelquefois je me perdois dans l'obscurité d'un bois touffu. Quelquefois en sortant d'un gouffre une agréable prairie réjouissoit tout à coup mes regards. Un mélange étonnant de la nature sauvage et de la nature cultivée, montroit par tout la main des hommes, où l'on eut cru qu'il n'avoient jamais pénétré. ${ }^{45}$

43 See Gayle Rubin: 'The Traffic in Women: Notes on the "Political Economy" of Sex', Toward an Anthropology of Women, ed. R. Reiter (New York: Monthly Review Press, 1975) 159-205.

44 See Nicole-Claude Mathieu, L'Anatomie politique: catégorisations et idéologies du sexe (Paris: Côté Femmes, 1991) and the notion of sexage developed by Colette Guillaumin (37).

$45 \mathrm{NH}, 77$; 'Sometimes, I would lose myself in the darkness of a dense brush. Sometimes, as I was leaving a dark chasm, a lovely field would rejoice at once my eyes. A strange mixture of wild and cultivated nature showed everywhere man's hand where it seemed it had never been.' 
Fiction, then, can be read both as an accomplice in the illusion of nature and as its strongest tool of critique, unmasking it while constructing it. And in this double gesture, one might see the specific work of the literary text in the eighteenth century: questioning the very possibility of natural signification both in language and in social signs, it makes fiction the space of a joint reflection on language as well as on political models. In both realms the artifice of nature is revealed to draw us back to a reading of the production of differences.

NATASHA LEE

Harvard University 